\title{
Protective Effect of Heme Oxygenase-1 Against Isoprenaline-induced Acute Myocardial Infarction in Rat in vivo
}

\section{Leyla Bulut Arsoy}

Goztepe Prof. Dr. Suleyman Yalcin City Hospital

\section{Gulsum Bulut Bingol}

Memorial Bahcelievler Hospital

Ozge Ozden

Memorial Bahcelievler Hospital

Hasan Tokdil ( $\square$ hasantokdil@gmail.com )

Istanbul University Cerrahpaşa

\section{Murat Giris}

Istanbul University

\section{Fatih Aydin}

Istanbul University

Canan Kucukgergin Basaran

Istanbul University

Gul Ozdemirler

Istanbul Yeni Yüzyıl University

\section{Research Article}

Keywords: Heme oxygenase-1, troponin-T, oxidative stres, isoprenaline, AMI, rat.

Posted Date: March 3rd, 2022

DOI: https://doi.org/10.21203/rs.3.rs-1286381/v1

License: (c) (i) This work is licensed under a Creative Commons Attribution 4.0 International License. Read Full License 


\section{Abstract}

Background: Heme oxygenase-1 (HO-1) is known to have anti-inflammatory, antiapoptotic and antioxidant effects in various diseases. In this study, we aimed to investigate whether HO-1 has a protective effect on isoprenaline (IP)-induced acute myocardial infarction (AMI) in rat.

Materials and methods: Rats were received $200 \mathrm{mg} / \mathrm{kg} \mathrm{IP}$, alone or together with cobalt protoporphyrin (CoPP) and zinc protoporphyrin (ZnPP), an inducer and an inhibitor of HO-1, respectively. Four hours after the IP application, rats were killed. Blood and hearts were removed. Troponin-T (TnT) levels were assayed in serum as an indicator of AMI. Dien conjugate levels, protein carbonyl levels and antioxidant defense system are assayed in heart tissues by spectrophotometric methods. HO-1 protein levels were quantitated by western blot analysis in heart tissues. The results were compared with those obtained from control groups.

Results: We confirmed AMI formation with higher serum TnT levels in IP-treated groups comparing to control groups. We found a significant elevation in HO-1 protein levels in IP plus CoPP-treated rats as compared to IP-treated rats, while serum TnT levels were observed to decrease at the same time. Protein carbonyl levels in heart tissues increased significantly in IP-treated groups compared with control groups. But, dien conjugate and antioxidant defense system remained unchanged.

Conclusions: As a conclusion, we may suggest that $\mathrm{HO}-1$ induction produces a protective effect against to myocardial damage occured by IP application in rat.

\section{Introduction}

The intrinsic defense mechanisms of the body are important in protecting organs from tissue damage in response to various stress conditions. Heme oxygenase-1 (HO-1) upregulation is one of such intrinsic defense systems. HO-1, also known as Hsp 32, is a member of $\mathrm{HO}$ protein family comprising three isoforms, HO-1, HO-2, HO-3 [1-3]. It catalyzes the first and rate-limiting step of heme degradation into ferrous iron, carbon monoxide and biliverdin, the latter being finally converted to bilirubin. These breakdown products have been reported to have antioxidant, anti-inflammatory, antiapoptotic effects which would be important in protecting the tissues from several stress conditions [4-6].

Cardiovascular diseases are the major health problem in the developed countries of the world. Growing evidence indicate that reactive oxygen species (ROS) and ROS-induced oxidative stress are essential in the processes underlying cardiovascular diseases $[7,8]$. It has been suggested that the overproduction of ROS lead to cardiomyocyte death by triggering many atherogenic events such as LDL oxidation, endothel dysfunction, vascular smooth muscle proliferation and migration [7]. Both invitro and in vivo experimental studies have shown that myocyte loss is generated by oxidative stress induced in I/R injury, myocard infarction and hypertension [8, 9]. Furthermore, oxidative stress hypothesis in cardiovascular disesases is also supported by clinical investigations [10]. On the other hand, several studies have shown that overexpression of stress proteins may protect myocardium against postischemic injury [11]. Since 
H0-1 has been shown to be upregulated in several stress conditions including diabetes [12], hypoxic lung disease [13], intestinal ischemia reperfusion [14], pancreatitis [15], its role has been also implicated in cardiovascular diseases $[6,16]$. However, there are limited experimental studies investigating the effect of HO-1 overexpression on cardiovascular diseases in in vivo conditions.

Induction of AMI by isoprenaline (IP), a synthetic $\beta$-adrenoreceptor agonist which is a widely used agent to generate $\mathrm{AMI}$ in rat, is a well-established experimental model to study the protective role of both exogenous agents and endogenous stres-inducible proteins [17]. For this reason, we aimed to investigate whether HO-1 overexpression has a protective effect on AMI induced by IP model. Furthermore we also wanted to search if oxidative stress is relevant to the presumed overexpression of HO-1 caused by AMI in our experimental conditions.

\section{Materials And Methods}

Male Sprague Dawley rats weighing between $180-220 \mathrm{~g}$ were procured from the Experimental Medical Research Institute of Istanbul University in the year of 2013. Rats were fed a standard laboratory chow and had free access to water. They were kept in wire-bottomed stainless steel cages. The experimental procedure used in this study met the guidelines of the Animal Care and Use Committee of Istanbul University (ethical approval is also given by the same institution's local ethical committee) and ARRIVE guidelines. All chemicals were purchased from Sigma-Aldrich (San Diego, USA).

\section{Experimental design}

Rats those divided into 6 groups, were pretreated with HO-1 mRNA inductors such as cobalt protoporphyrine (CoPP) and zinc protoporphyrine (ZnPP). CoPP ( $5 \mathrm{mg} / \mathrm{kg}$; i.p) and ZnPP ( $20 \mathrm{mg} / \mathrm{kg}$; i.p) were given two times with a 12-h interval. Myocardial infarction was induced by subcutaneous (sc)

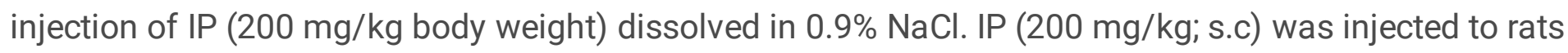
30 minutes after the last metalloporphyrine administrations. The rats were killed after 4 hours of IP administration. All experiments were performed during the years of 2013-2014.

1. Control group: $(n=7): \% 0.9 \mathrm{NaCl}$ (i.p) was injected twice at interval of 12 hours. $0.9 \% \mathrm{NaCl}$ injection was repeated 30 minutes after the last saline application.

2. CoPP group ( $n=4)$ : CoPP ( $5 \mathrm{mg} / \mathrm{kg}$; ip) was injected twice at interval 12 hours. $\% 0.9 \mathrm{NaCl}$ (s.c) was given to rats 30 minutes after the last CoPP application.

3. ZnPP group ( $n=4): Z n P P ~(20 \mathrm{mg} / \mathrm{kg}$; ip) was injected twice at interval 12 hours. $\% 0.9 \mathrm{NaCl}$ (s.c) was given to rats 30 minutes after the last $\mathrm{ZnPP}$ application.

4. IP group ( $\mathrm{n}=8)$ : \% $0.9 \mathrm{NaCl}$ (i.p) was injected twice at interval of 12 hours. IP ( $200 \mathrm{mg} / \mathrm{kg}, \mathrm{s.c}$ ) was given 30 minutes after the last saline application.

5. CoPP + IP group ( $\mathrm{n}=7)$ : CoPP (5 mg/kg; ip) was injected twice at interval 12 hours. IP $(200 \mathrm{mg} / \mathrm{kg}$, s.c) was given 30 minutes after the last CoPP application. 
6. $Z n P P+I P$ group ( $n=10): Z n P P(20 \mathrm{mg} / \mathrm{kg}$; ip) was injected twice at interval 12 hours. IP $(200 \mathrm{mg} / \mathrm{kg}$, s.c) was given 30 minutes after the ZnPP application.

After treatment, the animals were anesthetized by phenobarbital ( $50 \mathrm{mg} / \mathrm{kg}$ body weight), and sacrificed by cervical dislocation. The blood was obtained from vena cava inferior (v.c.i) and centrifuged at 2000 rpm to separate serum. The hearts were removed immediately, washed with ice-cold saline and kept in $80^{\circ} \mathrm{C}$ until use.

\section{Biochemical assays}

Serum TnT levels was assayed by immunochemiluminometric assay at Cardiology Institute of Istanbul University.

Dien conjugate (DC) levels was measured in tissue lipid extract at $233 \mathrm{~nm}$ spectrophometrically and calculated using a molar extinction coefficient of $2.52 \times 10^{4} \mathrm{M}^{-1} \mathrm{~cm}^{-1}$ [18]. Protein carbonyl (PC) levels were measured according to method described by Saji $\mathrm{K}$ et al [19]. This method is based on spectrophotometric detection of the reaction between 2,4-dinitrophennyhydrazine and protein carbonyl groups to form protein hydrazones. GSH levels were measured with 5,5ditiobis-(2-nitrobenzoate) at 412 $\mathrm{nm}$ in tissue homogenates [20].

Superoxide dismutase (SOD), glutathione peroxidase (GSH-Px) and glutathione transferase (GST) activities were determined in postmitochondrial fraction of tissues, which were separated by sequential centrifugation. SOD activity was assayed by its ability to increase the effect of riboflavin-sensitized photooxidation of o-dianisidine [21]. GSH-Px activity was measured using the method of Paglia and Valentine with cumene hydroperoxide as substrate [22]. GST activity was assayed by the spectrophotometric method using 1-chloro-2,4-dinitrobenzene as the substrate [23].

\section{H0-1 expression by western blot analysis}

Tissue hommogenates (10\%) were prepared in a buffer containing $50 \mathrm{mM}$ Tris- $\mathrm{HCl}, 1 \%$ Ipegal 630, 150 $\mathrm{mM} \mathrm{NaCl}, 0.5 \%$ sodium deoxycholate, $1 \%$ sodium dodesyl sulphate, PMSF, aprotinin and soy bean tripsin inhibitor (SBTI) by a hand homogenizator [24]. Homogenates were centrifuged at $4{ }^{0} \mathrm{C}, 13000 \mathrm{xg} 20 \mathrm{~min}$ and supernatants were seperated and protein content was determined. Samples containing $50 \mu \mathrm{g}$ protein per lane were electrophorized on a $12 \%$ gel in Tris-glycine buffer. SDS polyacrylamide gel electrophoresis was performed using Bio Rad's mini gel system according to Laemmli's method [25]. After electrophoresis, separated proteins were transferred onto Immobilon-PVDF membrane (Millipore), at 20V for $2 \mathrm{hr} 15 \mathrm{~min}$. [26]. The proteins on the membrane were blocked with $3 \%$ low-fat dried milk. After washing in phosphate buffer saline containing 1\% Tween 20 (PBS-T) three times, blots were treated with a 1: 3000 dilution of monoclonal primer antibody which recognizes HO-1 (W 27: sc-10789; Santa Cruz Biotechnology Inc., Santa Cruz, CA) and then washed with PBS-T for three times. Resulting immunocomplexes were exposed to 1:30000 horseradish peroxidase-conjugated goat antirabbit IgG (sc2004; Santa Cruz Biotechnology Inc., Santa Cruz, CA) for 2 hours. After washing with PBS-T, labeledantigen bands were visualized by an ECL western blotting detection reagent (sc-2048; Santa Cruz 
Biotechnology Inc., Santa Cruz, CA). The intensity of bands was semiquantified densitometrically by using Vilber Lourmat gel documentation system and Bio-1D V.97 software, an image analysing programme (Vilber Lourmat, Biotechnology Division, Torcy, France). The blots were stripped and subsequently reprobed with an anti-actin rabbit polyclonal with 1:1000 dilution (sc-1616-R; Santa Cruz Biotechnology Inc., Santa Cruz, CA) for normalization of loading. One protein sample from control group was applied onto lane 1 in each assay performed and its value was taken as $100 \%$ arbitrarily to compare with other samples. Results were expressed as relative densitometric unit (RDU).

Protein determination was carried out by a method using bicinchoninic acid [27].

\section{Statiscal analysis}

The results were expressed as mean \pm S.D. Experimental groups were compared using Kruskal-Wallis variance analysis test. Where significant effects were found, post hoc analysis using Mann-Whitney $U$ test was performed, and $p<0.05$ was considered to be statistically significant. The correlation coefficients were determined by Pearson's method.

\section{Results}

a. IP treatment caused significant increases in serum TnT levels as compared to control group. However, a significant decrease was found in serum TnT levels of CoPP + IP group when comparing this group with the IP group (Fig. 1, Table 1).

b. In heart tissue, HO-1 expression was observed to increase significantly in all groups compared to control. In addition, significant increases were also detected in CoPP and CoPP + IP groups compared to IP group (Fig. 2, Table1). 
Table 1

Biochemical parameters in serum and heart tissues of rats.

\begin{tabular}{|c|c|c|c|c|c|c|}
\hline & $\begin{array}{l}\text { Control } \\
(n: 7)\end{array}$ & $\begin{array}{l}\text { CoPP } \\
(n: 4)\end{array}$ & $\begin{array}{l}\text { ZnPP } \\
(n: 4)\end{array}$ & $\begin{array}{l}\text { IP } \\
(n: 8)\end{array}$ & $\begin{array}{l}\text { CoPP + IP } \\
(n: 7)\end{array}$ & $\begin{array}{l}\text { ZnPP + IP } \\
(n: 10)\end{array}$ \\
\hline HO-1 & 100.0 & 780.5 & 597.8 & 469.6 & 1165.2 & 617.4 \\
\hline$(\mathrm{RDU}) *$ & \pm 16.7 & $\pm 61.2^{a, b}$ & $\pm 49.4^{a}$ & $\pm 43.2^{a}$ & $\pm 69.9^{a, b}$ & $\pm 93.1^{a}$ \\
\hline TnT & 0.01 & 0.02 & 0.01 & 5.63 & 2.81 & 4.86 \\
\hline (ng/ml) & \pm 0.01 & \pm 0.02 & \pm 0.01 & $\pm 1.31^{a}$ & $\pm 0.52^{a, b}$ & $\pm 1.73^{\mathrm{a}}$ \\
\hline $\begin{array}{l}\text { PC } \\
(\mu \mathrm{mol} / \mathrm{g} \text { tissue })\end{array}$ & $\begin{array}{l}1.65 \pm \\
0.44\end{array}$ & $\begin{array}{l}1.84 \\
\pm 0.14\end{array}$ & $\begin{array}{l}1.56 \pm \\
0.35\end{array}$ & $\begin{array}{l}5.37 \pm \\
1.54^{\mathrm{a}}\end{array}$ & $\begin{array}{l}4.90 \pm \\
0.71^{\mathrm{a}}\end{array}$ & $\begin{array}{l}3.96 \pm \\
1.41^{\mathrm{a}}\end{array}$ \\
\hline $\begin{array}{l}\text { DK } \\
\text { ( } \mu \mathrm{mol} / \mathrm{g} \text { tissue })\end{array}$ & $\begin{array}{l}1.42 \pm \\
0.33\end{array}$ & $\begin{array}{l}1.29 \pm \\
0.26\end{array}$ & $\begin{array}{l}1.38 \pm \\
0.06\end{array}$ & $\begin{array}{l}1.37 \pm \\
0.17\end{array}$ & $\begin{array}{l}1.24 \pm \\
0.29\end{array}$ & $\begin{array}{l}1.37 \\
\pm 0.24\end{array}$ \\
\hline $\begin{array}{l}\text { GSH } \\
(\mu \mathrm{mol} / \mathrm{g} \text { tissue })\end{array}$ & $\begin{array}{l}2.36 \pm \\
0.40\end{array}$ & $\begin{array}{l}2.18 \pm \\
0.07\end{array}$ & $\begin{array}{l}2.12 \pm \\
0.12\end{array}$ & $\begin{array}{l}2.55 \pm \\
0.31\end{array}$ & $\begin{array}{l}2.58 \pm \\
0.56\end{array}$ & $\begin{array}{l}2.40 \pm \\
0.26\end{array}$ \\
\hline SOD & 10.7 & 10.6 & 10.9 & 11.9 & 11.0 & 12.0 \\
\hline (U/mg protein) & \pm 1.1 & \pm 1.4 & \pm 1.6 & \pm 1.7 & \pm 1.3 & \pm 2.7 \\
\hline GSH-Px & 247.0 & 272.0 & 267.8 & 214.0 & 216.3 & 212.6 \\
\hline $\begin{array}{l}\text { (nmol NADPH/ } \\
\text { min/mg protein) }\end{array}$ & \pm 45.8 & \pm 16.8 & \pm 58.1 & \pm 49.8 & \pm 40.1 & \pm 45.0 \\
\hline \multirow{2}{*}{$\begin{array}{l}\text { GST (nmol/min/mg } \\
\text { protein) }\end{array}$} & 53.6 & 45.2 & 54.1 & 54.7 & 46.4 & 58.8 \\
\hline & \pm 6.4 & \pm 5.4 & \pm 7.3 & \pm 7.6 & \pm 10.8 & \pm 7.9 \\
\hline
\end{tabular}

* Relative densitometric units.

a $p<0.05$ : compared to control

${ }^{b} \mathrm{p}<0.05$ : compared to IP

Furthermore, there was a significant inverse correlation between HO-1 expression and serum TnT levels ( $r$ $=-0.814 ; p<0.01$ ) (Fig. 3).

c. Significant increases in protein carbonyl levels were observed in IP, CoPP + IP and ZnPP + IP groups compared to control groups (Control, CoPP and ZnPP groups). But, intergroup significance was not detected (Fig. 4, Table 1). On the other hand dien konjugate levels remained unchanged (Table 1). 
d. Neither GSH levels nor antioxidant enzyme activities as antioxidant defense system changed comparing with control. In addition, intergroup significance was not found (Table 1).

\section{Discussion}

HO-1 induction is suggested to enhance cellular tolerance and resistance capacity against tissue damage in various pathological states. Studies have demonstrated that induction of HO-1 by chemical inducers provides protection in cardiac transplant rejection [28], hypoxic lung disease [13], intestinal ischemia reperfusion injury. In addition, HO-1 overexpression by gene transfer has been reported to protect against hypoxic lung diseases [29]. HO-1 has also been shown to have cytoprotective effects in $\mathrm{CCl}_{4}$ - [30] and ethanol-induced [31], liver damage, pancreatitis [32] and diabetes [33]. The role of HO-1 in cardiac homeostasis was first implicated in a study showing the increase in HO-1 expression in heart in response to hyperthermia [34]. There are studies, it was demonstrating the absence of HO-1 which exacerbated remodelling in hypercholesterolemic mouse model [35] and ischemia/R- induced myocardial damage in diabetic mice [36]. On the other hand studies using cardiac-specific HO-1 transgenic mice revealed that HO-1 overexpression played a protective role against myocardial damage in I/R model [37] and also in heart failure model [38]. Lakkisto et al. have shown that HO-1 has antiapoptotic and antiproliferative effects on rat myocytes after AMI produced by coronary artery ligation [39-41]. In one of these studies, they have suggested that HO-1 induction might increase the life span of cardiomyocytes by enhancing the vascularization. In a recent study, luteolin has been reported to have a protective effect on myocardial infarction produced by IP administration which might be related to HO-1 induction in rats with AMI [42]. In our study, by a different approach, we aimed to investigate the protective role of $\mathrm{HO}-1$ in invivo experimental IP-induced acute AMI model by using exogenous HO-1 mRNA inductors such as CoPP and ZnPP. Isoprotrenol, a potent synthetic cathecholamine when given to animals at toxic doses, produces "infarct like" lesions in the heart similar to those found in human after AMI [43-45]. Investigators have used different doses of IP such as $110 \mathrm{mg} / \mathrm{kg}$ [44], $150 \mathrm{mg} / \mathrm{kg}$ [45], $200 \mathrm{mg} / \mathrm{kg}$ [46] to produce AMI in rats. In these studies, the presence of AMI has been confirmed by assessing plasma CK, AST and LDH activities at different time periods in plasma. However, the assessment of cardiac TnT and troponin-I (Tnl) are currently used as the most sensitive and specific markers of AMI.

In the present study, we administered IP at the dose of $200 \mathrm{mg} / \mathrm{kg}$ to rats and showed the presence of cardiomyocyte necrosis by detecting significant elevations in plasma TnT levels in all IP-given groups (IP, $\mathrm{CoPP}+\mathrm{IP}, \mathrm{ZnPP}+\mathrm{IP}$ ) compared to their matching control groups (control, CoPP and ZnPP) after 4 hours. But we determined a significant decrease in plasma TnT levels of CoPP + IP group when we compared it to IP group. We think that CoPP, the inducer of $\mathrm{HO}-1$, might be responsible for this decrease seen in CoPP + IP group.

Regarding to the HO-1 protein levels in heart tissue, significant increases were found in all groups as compared to control group. This shows that both CoPP and ZnPP cause induction of HO-1 in the heart of rats. The metalloporphyrins are extensively used for HO-1 induction or inhibition. Although CoPP and ZnPP are known to induce HO-1 mRNA induction, ZnPP is generally used for inhibition of enzyme activitiy 
[47-50]. In our study, we found that, HO-1 expression increased in the groups given ZnPP (ZnPP and $\mathrm{ZnPP}+\mathrm{IP}$ ) as compared to control, too. But this increase was not as high as those seen in the groups given CoPP (CoPP and CoPP + IP). In addition, HO-1 levels were also found to elevate in both CoPP and $\mathrm{CoPP}+\mathrm{IP}$ groups as compared to IP group. This increases seen in HO-1 expression, concomitant with the decline in serum TnT levels in CoPP + IP group confirmed that HO-1 induction created a protection against cardiomyocyte loss after AMI. But, we did not observe any change in both HO-1 expression in heart tissue and serum TnT levels in ZnPP + IP group as compared to IP group. Although ZnPP induces HO-1, it didn't show protective effect on myocardium after AMI. We think that ZnPP might have an inhibitory effect on HO-1 enzyme activity.

On the other hand, it has been reported that the increased lipid oxidation [51-53] and decreased antioxidant system $[52,53]$ contribute to oxidative stress and affect the pathogenesis of AMI. In this study, we did not find any change either in dien conjugate levels or in antioxidative system in heart tissues of rats after AMI. However, tissue protein carbonyl levels were found to be higher in all groups with AMI (IP, CoPP + IP, ZnPP + IP) than their matching control groups (control, CoPP, ZnPP). Although there was not a statistical significance among groups, the increases observed in PK levels together with the increases in $\mathrm{HO}-1$ which is a stress-inducible protein, may be suggested to reflect the oxidative stress condition in the cell. Indeed, there are studies showing that the increases in HO-1 mRNA expression might be an indicator of oxidative stress [54].

In summary, $\mathrm{HO}-1$ induction together with decrease in serum TnT levels exhibits a protection against cardiomyocyte loss after AMI generated by IP. Recent studies have suggested that HO-1 up-regulation by pharmacological modulation or gene transfer might have a promising role in planning a new therapetic strategies in AMI in the future $[55,56]$. Taken together, our finding suggest that, the induction of HO-1 may be an important tool for enhancing the recovery of myocardial infarction and protection against pathological changes in myocardium.

\section{Declarations}

\section{Ethics Approval}

The ethical approval has gained from the local ethical board of Istanbul University (No:2012/10) and the trial has begun after the ethical approval. The experimental procedure used in this study met the guidelines of the Animal Care and Use Committee of Istanbul University (ethical approval is also given by the same institution's local ethical committee) and ARRIVE guidelines. In the natüre of this is being an animal study, informed consent could not be obtained.

\section{Consent for Publication}

By submitting the article, all authors are agreeing the publication. 
All the datas collected during the study is available and accessable.

\section{Conflict of Interest}

All authors declare there is no conflict of interest.

\section{Funding}

This work was supported by the Research Fund of the University of Istanbul (No. 22240)

\section{Authors' Contribution}

Our study has demonstrated that heme-oxygenase- 1 has a protective effect in the rats with isoprenaline induced myocardial infarction. There are still a need for human studies and this results are hopeful for the future treatment algorhytms.

\section{References}

[1] Idriss NK, Blann AD, Lip GY. Hemoxygenase-1 in cardiovascular disease. J Am Coll Cardiol 2008; 52 : 971-978.

[2] Wu ML, HoYC and Yet SF. A central role of heme oxygenase-1 in cardiovascular protection. Antioxidants \& Redox signaling 2011;15: 1835-1846.

[3] Lakkisto P, Palojoki E, Bäcklund T, Saraste A, Tikkanen I, Voipio-Pulkki LM ve ark.

Expression of heme oxygenase- 1 in response to myocardial infarction in rats. $\mathrm{J} \mathrm{Mol} \mathrm{Cell} \mathrm{Cardiol} \mathrm{2002;}$ 34: 1357-1365.

[4] Yao P, Li K, Song F, Zhou S, Sun X, Zhang X, Nüssler AK, Liu L. Heme oxygenase-1

upregulated by ginkgo biloba extract: potential protection against ethanol-induced oxidative live damage. Food Chem Toxicol 2007; 45: 1333-1342.

[5] Immenschuh S, Schröder H. Heme oxygenase-1 and cardiovascular disease. Histol Histopathol 2006; 21: 679-685.

[6] Novo G, Cappello F, Rizzo M, Fazio G, Zambuto S, Tortorici E ve ark. Hsp60 and heme oxygenase-1 (Hsp32) in acute myocardial infarction. Transl Res 2011; 157: 285-292.

[7] Alamdari DH, Ghayour-Mobarhan M, Tavallaie S, Parizadeh MR, Moohebati M, Ghafoori F ve ark. Prooxidant-antioxidant balance as a new risk factor in patients with angiogaphically defined coronary artery disease. Clin Biochem 2008; 41: 375-380.

[8] Giordano FJ. Oxygen, oxidative stress, hypoxia, and heart failure. J Clin Invest 2005; 115: 500-508. 
[9] Kaul N, Siveski-lliskovic N, Hill M, Slezak J, Singal P. Free radicals and the heart. J Pharmacol Toxicol Methods 1993; 30: 55-67.

[10] Singh U, Jialal I. Oxidative stres and atherosclerosis. Pathophysiology 2006; 13: 129-142.

[11] Yet SF, Tian R, Layne MD, Wang ZY, Maemura K, Solovyeva M ve ark. Cardiac-specific expression of heme oxygenase- 1 protects against ischemia and reperfusion injury in transgenic mice. Circ Res 2001; 89: 168-173.

[12] Kruger AL, Peterson SJ, Schwartzman ML, Fusco H, McClung JA, Weiss M ve ark. Up regulation of heme oxygenase provides vascular protection in an animal model of diabetes through its antioxidant and antiapoptotic effects. J Pharmacol Exp Ther 2006; 319: 1144-1152.

[13] Otterbein LE, Kolls JK, Mantell LL, Cook JL, Alam J, Choi AM. Exogenous administration of heme oxygenase- 1 by gene transfer provides protection against hyperoxia induced lung injury. $\mathrm{J}$ Clin Invest 1999; 103: 1047-1054.

[14] Ryter SW, Alam J and Choi AMK. Heme Oxygenase-1/Carbon monoxide: From basic science to therapeutic applications. Physiol Rev 2006; 86:583-650.

[15] Nakamichi I, Habtezion A, Zhong B, Contag CH, Butcher EC, Omary MB. Hemin activated macrophages home to the pancreas and protect from acute pancreatitis via heme oxygenase- 1 induction. J Clin Invest 2005; 115: 3007-3014.

[16] Lakkisto P, Siren JM, Kytö V, Forsten H, Laine M, Pulkki K ve ark. Heme oxygenase-1 induction protects the heart and modulates cellular and extracellular remodelling after myocardial infarction in rats. Exp Biol Med (Maywood) 2011; 236: 1437-1448.

[17] Rajadurai M, Prince PSM. Preventive effect of naringin on lipid peroxides and antioxidants in isoproterenol-induced cardiotoxicity in Wistar rats: Biochemical and histopathological evidences. Toxicology 2006: 228: 259-268.

[18] Buege JA, Aust JD. Microsomal lipid peroxidation. Method Enzymol 1978; 52: 302-310.

[19] Saji K, Fukumoto Y, Suzuki J, Fukui S, Nawata J, Shimokawa H. Colchine, a microtubule depolymerizing agent, inhibits myocardial apoptosis in rats. Tohoku J Exp Med 2007; 213: 139 -148.

[20] Beutler E, Duron O, Kelly BM. Improved method for the determination of blood glutathione. J Lab Clin Med 1963; 61: 882-888.

[21] Mylorie AA, Collins H, Umbles C, Kyle J. Erythrocyte superoxide dismutase activity and other parameters of copper status in rats ingesting lead acetate. Toxicol Appl Pharmacol 1986; 82: 512-520. 
[22] Lawrence RA, Burk RF. Glutathione peroxidase activity in selenium deficient rat liver. Biochem Biophys Res Commun 1976; 71: 952-958.

[23] Habig HW,Tacoby WB. The first enzymatic step in mercaptüric acid formation, J Biol Chem 1974; 3 : 7130-7139.

[24] Dambach DM, Durham SK, Laskin JD, Laskin DL. Distinct roles of NF-kappaB p50 in the regulation of acetaminophen-induced inflammatory mediator production and hepatotoxicity. Toxicol Appl Pharmacol 2006; 211: 157-165.

[25] Laemmli UK: Cleavage of structural proteins during assembly of the head of bacteriophage T4. Nature 1970; 227: 680-685.

[26] Towbin H, Stashelin T, Gordon J. Electrophoretic transfer of proteins from polyacrylamide gels to nitrocellulose sheets: procedures and some applications. Proc Natl Acad Sci USA 1979; 76: 4350-4354.

[27] Smith PK, Krohn RI, Hermanson GT, Mallia AK, Gartner FH, Provenzano MD ve ark. Measurement of protein using bicinchoninic acid. Anal Biochem 1985; 150: 76-85.

[28] Soares MP, Lin Y, Anrather J, Csizmadia E, Takigami K, Sato K ve ark. Expression of heme oxygenase1 can determine cardiac xenograft survival. Nat Med 1998; 4: 91-98.

[29] Wasserberg N, Pileggi A, Salgar SK, Ruiz P, Ricordi C, Inverardi L ve ark. Heme oxygenase1 upregulation protects against intestinal ischemia/reperfusion injury: a laboratory based study. Int $\mathrm{J}$ Surg 2007; 5: 216-224.

[30] Otterbein LE, Kolls JK, Mantell LL, Cook JL, Alam J, Choi AM. Exogenous administration of heme oxygenase- 1 by gene transfer provides protection against hyperoxia induced lung injury. $\mathrm{J}$ Clin Invest 1999; 103: 1047-1054.

[31] Nakahira K, Takahashi T, Shimizu H, Maeshima K, Uehara K, Fujii H ve ark.

Protective role of heme oxygenase- 1 induction in carbontetrachloride induced hepatotoxicity. Biochem Pharmacol 2003; 66: 1091-105.

[32] Liu LG, Yan H, Zhang W, Yao P, Zhang XP, Sun XF et al. Induction of heme oxygenase-1 in human hepatocytes to protect them from ethanol-induced cytotoxicity. Biomed Environ Sci 2004; 17: 315-326.

[33] Kruger AL, Peterson SJ, Schwartzman ML, Fusco H, McClung JA, Weiss M ve ark. Up regulation of heme oxygenase provides vascular protection in an animal model of diabetes through its antioxidant and antiapoptotic effects. J Pharmacol Exp Ther 2006; 319: 1144-1152.

[34] Ewing JF, Raju VS, Maines MD. Induction of heart heme oxygenase-1 (HSP32) by hyperthermia: possible role in stress-mediated elevation of cyclic $3^{\prime}: 5^{\prime}$-guanosine monophosphate. J Pharmacol Exp Ther 1994; 271: 408- 414. 
[35] Yet SF, Layne MD, Liu X, Chen YH, Ith B, Sibinga NES and Perrella MA. Absence of heme oxygenase-1 exacerbates atherosclerotic lesion formation and vascular remodeling. FASEB J 2003; 17: 1759-1761.

[36] Liu X, Wei J, Peng DH, Layne DH and Yet SF. Absence of heme oxygenase-1 exacerbates myocardial ischemia/reperfusion injury in diabetiz mice. Diabetes 2005; 54: 778-784.

[37] Yet SF, Tian R, Layne MD, Wang ZY, Maemura K, Solovyeva M ve ark. Cardiac-specific expression of heme oxygenase- 1 protects against ischemia and reperfusion injury in transgenic mice. Circ Res 2001; 89: 168-173.

[38] Wang G, Hamid T, Keith RJ, Zhou G, Partridge CR, Xiang X ve ark. Cardioprotective and antiapoptotic effects of heme oxygenase-1 in the failing heart. Circulation 2010; 121: 1912-1925.

[39] Lakkisto P, Siren JM, Kytö V, Forsten H, Laine M, Pulkki K ve ark. Heme oxygenase-1 induction protects the heart and modulates cellular and extracellular remodelling after myocardial infarction in rats. Exp Biol Med (Maywood) 2011; 236: 1437-1448.

[40] Lakkisto P, Palojoki E, Bäcklund T, Saraste A, Tikkanen I, Voipio-Pulkki LM ve ark. Expression of heme oxygenase-1 in response to myocardial infarction in rats. J Mol Cell Cardiol 2002; 34: 1357-1365.

[41] Sun GB, Sun X, Wang M, Ye JX, Si JY, Xu HB ve ark. Oxidative stres suppression by luteolin-induced heme oxygenase-1 expression. Toxicol Appl Pharmacol 2012; 265: 229-240.

[42] Pinelli A, Trivulzio S, Tomasoni L, Bertolini B, Brenna S, Bonacina E ve ark. Myocardial infarction noninvasively induced in rabbits by administering isoproterenol and vasopressin: protective effects exerted by verapamil. Fund Clin Pharmacol 2008; 18: 657- 667.

[43] Rajadurai M, Prince PSM. Preventive effect of naringin on lipid peroxides and antioxidants in isoproterenol-induced cardiotoxicity in Wistar rats: Biochemical and histopathological evidences. Toxicology 2006: 228: 259-268.

[44] Anandan R, Mathew S, Sankar TV, Nair PGV. Protective effect of n-3 polyunsaturated fatty acids concentrate on isoproterenol-induced myocardial infarction in rats. Prostaglandins Leukot Essent Fatty Acids 2007; 76: 153 -158.

[45] Prince PSM, Karthick M. Preventive effect of rutin on lipid, lipoproteins and ATPases in normal and isoproterenol-induced myocardial infarction in rats. J Biochem Mol Toxicol 2007; 22: 1- 6.

[46] Vivek B, Wilson E, Nithya Devi SV, Velmurugan C, Kannan M. Cardioprotective activity of shilajit in isoproterenol - induced myocardial infarction in rats: A biochemical and histopathological evaluation. Int J Res Phytochem Pharmacol 2011; 1: 28-32.

[47] Mitani K, Fujita H, Fukuda Y, Kappas A, Sassa S. The role of inorganic metals and metalloporphyrins in the induction of haem oxygenase and heat-shock protein 70 in human hepatoma cells. Biochem $\mathrm{J}$ 
1993; 290: 819-825.

[48] Iwasashi H, Suzuki M, Unno M, Utiyama T, Oikawa M, Kondo N ve ark. Inhibition of heme oxygenase ameliorates sepsis-induced liver dysfunction in rats. Surg Today 2003; 33: 30-8.

[49] Tüzüner E, Liu L, Shimada M, Yilmaz E, Glanemann M, Settmacher U ve ark. Heme oxygenase-1 protects human hepatocytes in vitro against warm and cold hypoxia. J Hepatol 2004; 41: 764-72.

[50] Wen T, Wu ZM, Liu Y, Tan YF, Ren F, Wu H. Upregulation of heme oxygenase-1 with hemin prevents Dgalactosamine and lipopolysaccharide-induced acute hepatic injury in rats. Toxicol 2007; 237: 184-193.

[51] Rajadurai M, Prince PSM. Preventive effect of naringin on lipid peroxides and antioxidants in isoproterenol-induced cardiotoxicity in Wistar rats: Biochemical and histopathological evidences. Toxicology 2006; 228: 259-268.

[52] Vennila L, Pugalendi KV. Protective effect of sesamol against myocardial infarction caused by isoproterenol in Wistar rats. Redox Report 2010; 15: 36-42.

[53] Ganesan B, Buddhan S, Anandan R, Sivakumar R, AnbinEzhilan R. Amtioxidant defense of betaine against isopremaline-induced myocardial infarction in rats. Mol Biol Rep 2009; doi: 10.1007/s11033-0099508-4.

[54] Lavrovsky Y, Song CS, Chatterjee B, Roy AK. Age-dependent increase of heme oxygenase-1 gene expression in the liver mediated by NFkappaB. Mech Ageing Dev 2000; 114: 49-60.

[55] Saji K, Fukumoto Y, Suzuki J, Fukui S, Nawata J, Shimokawa H. Colchine, a microtubule depolymerizing agent, inhibits myocardial apoptosis in rats. Tohoku J Exp Med 2007; 213; 139 -148.

[56] Tang YL, Tang Y, Zhang YC, Qian K, Shen L, Phillips MI. Improved graft mesenchymal stem cell survival in ischemic heart with a hypoxia-regulated heme oxygenase 1 vector. J Am Coll Cardiol 2005; 46: 1339-1350.

\section{Figures}




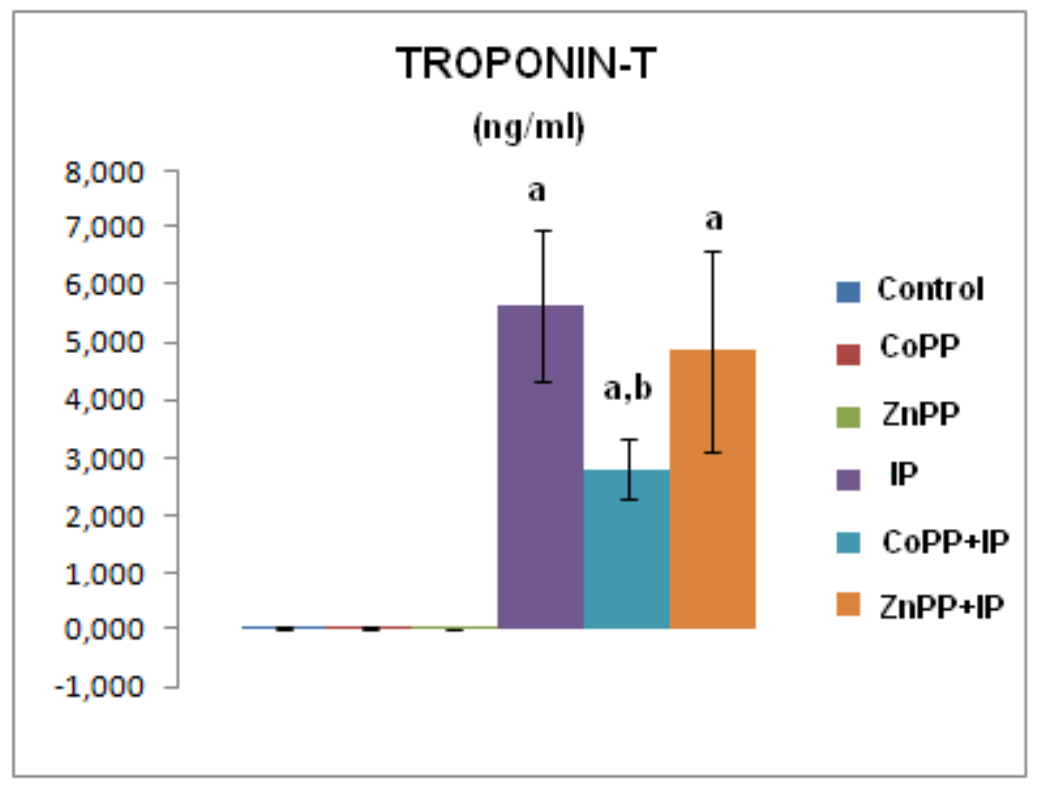

Figure 1

Serum Troponin-T (TnT) levels in rats those HO-1 was induced by CoPP or ZnPP.

a $p<0.05$ : compared to control

${ }^{b} p<0.05$ : compared to IP 
HO-1

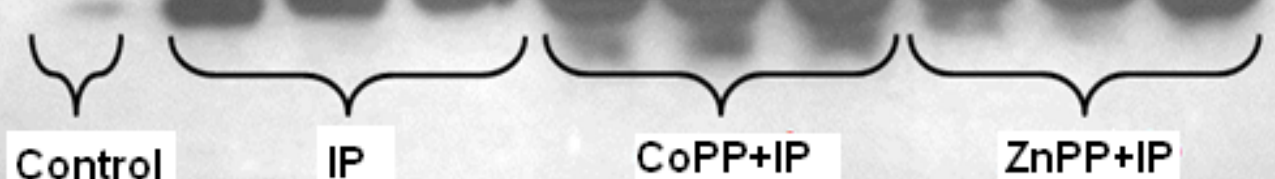

Actin

$\mathrm{HO}-1$

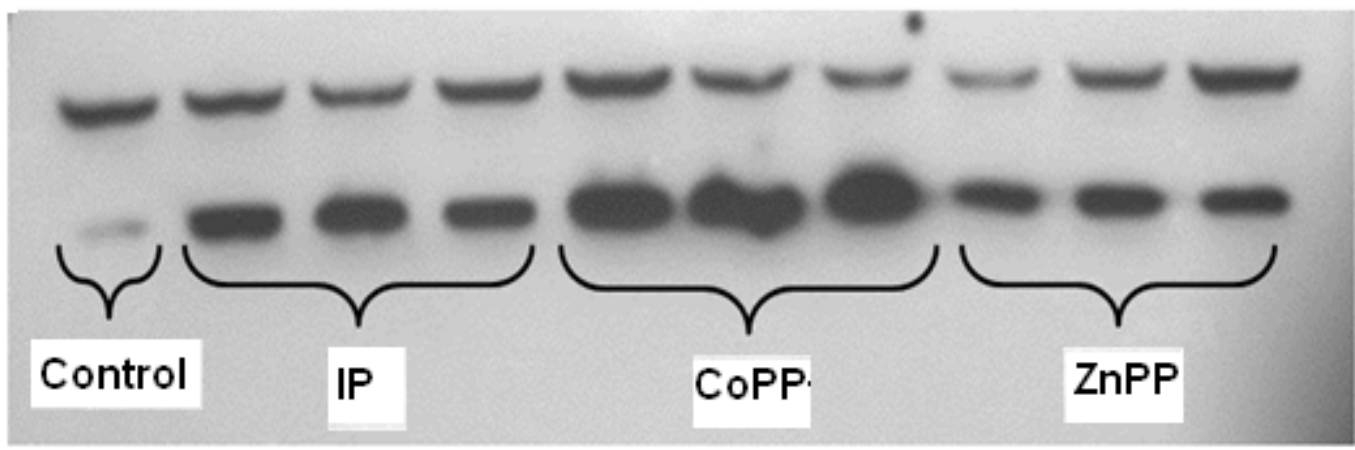

Figure 2

Western blot profiles for HO-1 induction in heart tissues of rats those $\mathrm{HO}-1$ was induced by CoPP or ZnPP.

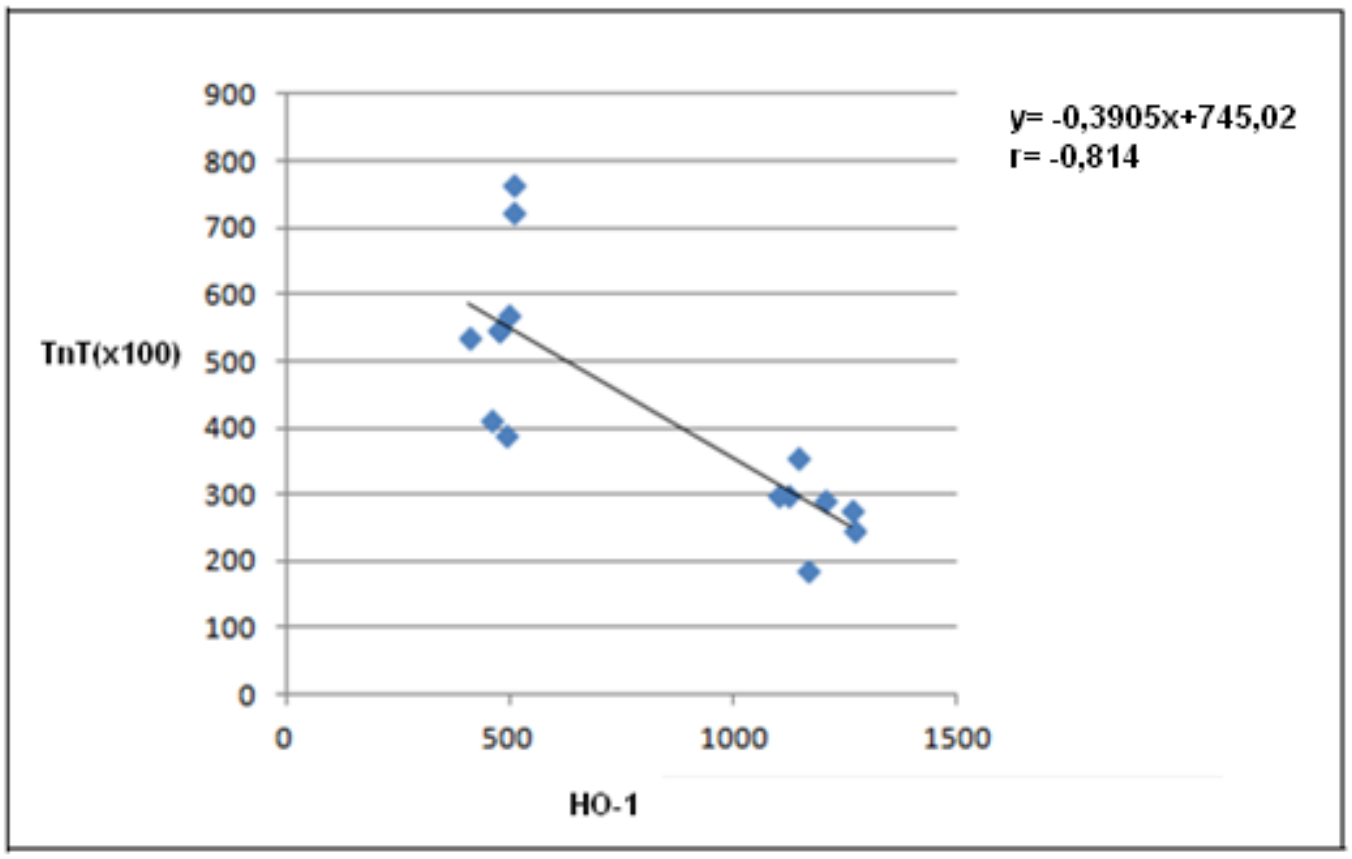


Figure 3

Inverse correlation between HO-1 expression and serum TnT levels.

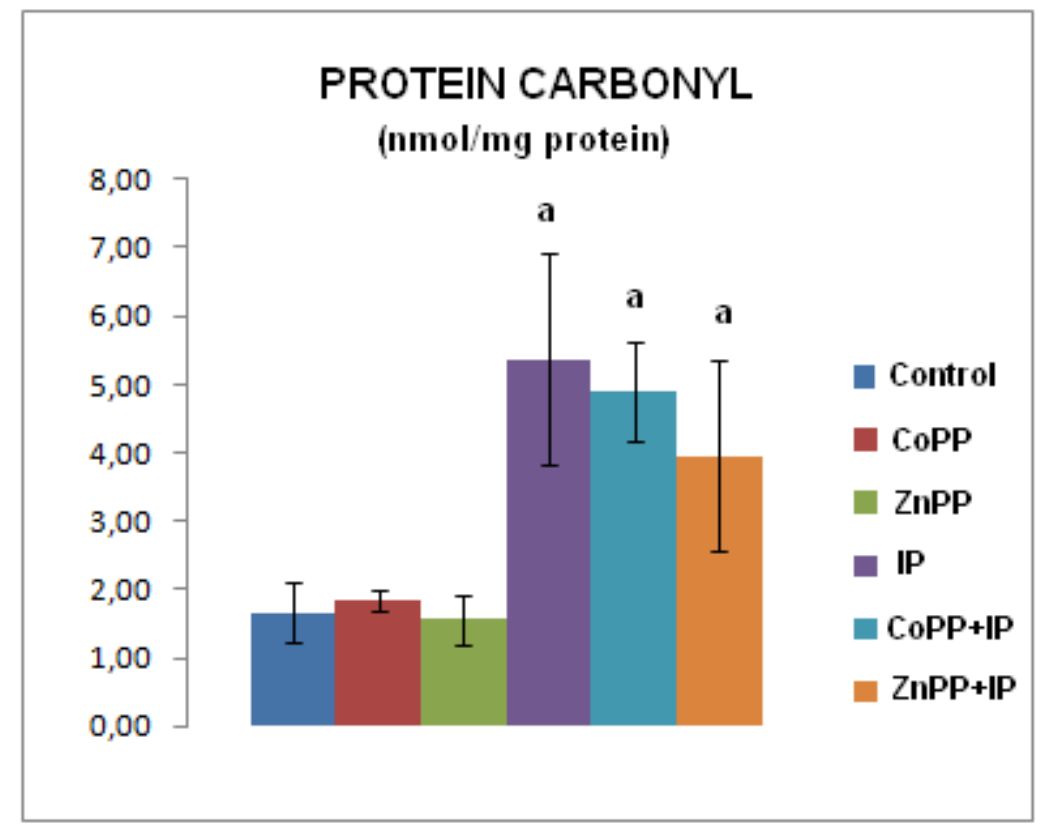

Figure 4

Protein carbonyl levels in heart tissues of rats those HO-1 was induced by CoPP or ZnPP.

a $p<0.05$ : compared to control

${ }^{b} p<0.05:$ compared to IP 